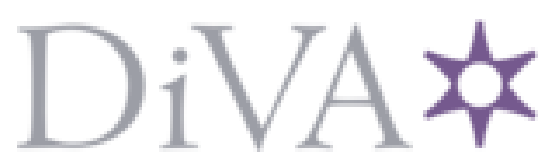

http://www.diva-portal.org

\title{
Postprint
}

This is the accepted version of a paper published in Alcheringa. This paper has been peer-reviewed but does not include the final publisher proof-corrections or journal pagination.

Citation for the original published paper (version of record):

Wretman, L., Kear, B. (2013)

Bite marks on an ichthyodectiform fish from Australia: possible evidence of trophic interaction in an Early Cretaceous marine ecosystem.

Alcheringa, 38

http://dx.doi.org/10.1080/03115518.2014.848692

Access to the published version may require subscription.

N.B. When citing this work, cite the original published paper.

Permanent link to this version:

http://urn.kb.se/resolve?urn=urn:nbn:se:uu:diva-213756 
This article was downloaded by: [Uppsala universitetsbibliotek]

On: 20 November 2013, At: 09: 36

Publisher: Taylor \& Francis

Informa Ltd Registered in England and Wales Registered Number: 1072954 Registered office: Mortimer House, 37-41 Mortimer Street, London W1T 3J H, UK

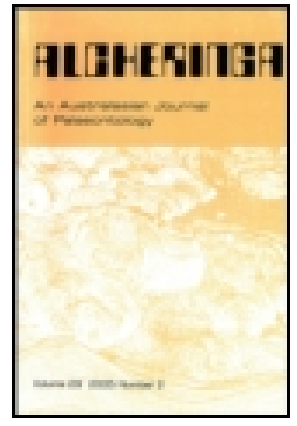

Alcheringa: An Australasian J ournal of Palaeontology

Publication details, including instructions for authors and subscription information: http:// www.tandfonline.com/loi/talc20

\section{Bite marks on an ichthyodectiform fish from Australia: possible evidence of trophic interaction in an Early Cretaceous marine ecosystem}

Lovisa Wretman \& Benjamin P. Kear

Published online: 29 Oct 2013.

To cite this article: Lovisa Wretman \& Benjamin P. Kear , Alcheringa: An Australasian J ournal of Palaeontology (2013): Bite marks on an ichthyodectiform fish from Australia: possible evidence of trophic interaction in an Early Cretaceous marine ecosystem, Alcheringa: An Australasian J ournal of Palaeontology, DOI: 10.1080/ 03115518. 2014.848692

To link to this article: http:// dx.doi.org/ 10.1080/03115518.2014.848692

\section{PLEASE SCROLL DOWN FOR ARTICLE}

Taylor \& Francis makes every effort to ensure the accuracy of all the information (the "Content") contained in the publications on our platform. However, Taylor \& Francis, our agents, and our licensors make no representations or warranties whatsoever as to the accuracy, completeness, or suitability for any purpose of the Content. Any opinions and views expressed in this publication are the opinions and views of the authors, and are not the views of or endorsed by Taylor \& Francis. The accuracy of the Content should not be relied upon and should be independently verified with primary sources of information. Taylor and Francis shall not be liable for any losses, actions, claims, proceedings, demands, costs, expenses, damages, and other liabilities whatsoever or howsoever caused arising directly or indirectly in connection with, in relation to or arising out of the use of the Content.

This article may be used for research, teaching, and private study purposes. Any substantial or systematic reproduction, redistribution, reselling, loan, sub-licensing, systematic supply, or distribution in any form to anyone is expressly forbidden. Terms $\&$ Conditions of access and use can be found at http:// www.tandfonline.com/page/terms-and-conditions 


\title{
Bite marks on an ichthyodectiform fish from Australia: possible evidence of trophic interaction in an Early Cretaceous marine ecosystem
}

\author{
LOVISA WRETMAN and BENJAMIN P. KEAR
}

Wretman, L. \& KeAR, B.P., 2013. Bite marks on an ichthyodectiform fish from Australia: possible evidence of trophic interaction in an Early Cretaceous marine ecosystem. Alcheringa 38, 000-000. ISSN 0311-5518.

\begin{abstract}
A well-preserved fish skull from late Albian deposits of the Allaru Mudstone near Richmond in Queensland displays a conspicuous V-shaped pattern of indentations, punctures and depression fractures consistent with a vertebrate bite trace. This is the first direct evidence of trophic interaction between vertebrates within an Early Cretaceous marine ecosystem from Australia. The specimen is taxonomically referable to the largebodied ( $\mathrm{ca} 1 \mathrm{~m}$ snout-tail length) ichthyodectiform Cooyoo australis, but the size and spacing of the tooth marks is incompatible with attack by a conspecific individual. The lack of osseous growths concordant with healing also suggests that the bite occurred shortly before or after the animal's death. Comparison with the dentitions of other coeval vertebrates indicates compatible tooth arrangements in longirostrine amniote predators such as polycotylid plesiosaurians, ornithocheiroid pterosaurs and especially the ichthyosaurian Platypterygius. The implications of this as a potential predator-prey association are that Early Cretaceous actinopterygians occupied middle-level trophic niches and were in turn consumed by higher-level amniote carnivores, similar to many extant marine vertebrate communities of today.
\end{abstract}

Lovisa Wretman [lovisa.wretman@ebc.uu.se], Subdepartment of Evolution and Development, Department of Organismal Biology, Uppsala University, Norbyvägen 18A, SE-752 36 Uppsala, Sweden (address for correspondence); Benjamin P. Kear [benjamin.kear@geo.uu.se], Palaeobiology Programme, Department of Earth Sciences, Uppsala University, Villavägen 16, SE-752 36 Uppsala, Sweden. Received 8.8.2013, revised 17.9.2013, accepted 23.9.2013.

Key words: bone modification, feeding traces, stem teleosts, marine amniotes.

TROPHIC INTERACTIONS between Mesozoic marine vertebrates have been reconstructed from preserved gut contents (e.g., Pollard 1968, Wilby \& Martill 1992, Maisey 1994, Shimada 1997, Sato \& Tanabe 1998, Cicimurri \& Everhart 2001, Kear et al. 2003, Everhart 2004a, McHenry et al. 2005, Kear 2006, Martin \& Fox 2007, O'Keefe et al. 2009), coprolites (e.g., Martin \& Kennedy 1988, Maisey 1994, Kear 2006, Everhart 2007, Everhart et al. 2010, Harrell \& Schwimmer 2010, Eriksson et al. 2011), regurgitates (e.g., Hattin 1996, Oji et al. 2003, Salamon et al. 2012), broken shells/ bones/teeth (e.g., Lingham-Soliar 2004, Zatón \& Salamon 2008, Vullo 2011) and, most evocatively, bite marks (e.g., Kauffman \& Kesling 1960, Kauffman 1972, 2004, Martill 1990, 1996, Ward \& Hollingworth 1990, Neumann 2000, Kear \& Godthelp 2008, Klompmaker et al. 2009, Kellner et al. 2010, Kauffman \& Swado 2013). Because bite traces directly reflect the actions of living animals, they can also provide information on behaviours such as feeding strategies and social activities. Documented examples include predation and/or scavenging by selachians (Schwimmer et al. 1997, Shimada 1997, Everhart 2004b, 2005, Shimada \&

(C) 2013 Association of Australasian Palaeontologists http://dx.doi.org/10.1080/03115518.2014.848692
Hooks 2004, Everhart \& Hamm 2005, Rothschild et al. 2005, Kaddumi 2006, Barnes \& Hiller 2010, Shimada et al. 2010), mosasauroids (Barnes \& Hiller 2010, Einarsson et al. 2010) and marine crocodylians (Forrest 2003), intraspecific combat in ichthyosaurians (Zammit \& Kear 2011) and thallatosuchians (Frey et al. 2002) and dramatically violent encounters between plesiosaurians (Thulborn \& Turner 1993) and mosasauroids (Lingham-Soliar 1995, 2004, Everhart 2008). In contrast, incidences of bite marks on Mesozoic fishes are rare, which is surprising given their abundance in many deposits. Nevertheless, accounts exist of healed punctures on hybodontiform shark fin spines (Maisey 1978) and embedded large lamniform teeth/cut marks on actinopterygian skull elements and vertebrae (Shimada \& Everhart 2004, Shimada \& Fielitz 2006). This paper provides a novel addition to this currently scant bite trace record: an ichthyodectiform teleost skull from the Early Cretaceous of Australia that exhibits bone modifications consistent with attack by a large vertebrate predator.

\section{Geological setting}

The fish skull, Kronosaurus Korner (KK) regional museum (an accredited Queensland State Government repository for significant natural history and cultural 
artifacts) R0457, was found preserved within a limestone concretion probably derived from bedrock exposures of the Allaru Mudstone along the Flinders River in central-northern Queensland, Australia (see Henderson \& Kennedy 2002, p. 234, fig. 1 for a geological map of the area). KK R0457 was collected by local property owners David Goodman and Wayne Rhodes from a weathering residuum of unconsolidated alluvial sands at 'Wayne Rhodes rapids' $\left(20^{\circ} 45^{\prime} 40.37^{\prime \prime} \mathrm{S}, 143^{\circ}\right.$ $10^{\prime} 58.00^{\prime \prime} \mathrm{E}$ ), about $6 \mathrm{~km}$ east of the town of Richmond. The Allaru Mudstone constitutes a subdivision of the Rolling Downs Group (Eromanga Basin) and has a conformable lower boundary with the Toolebuc Formation and an upper conformity with the Mackunda Formation using the northern Eromanga Basin nomenclatural scheme (see Cook 2012 for summary). Senior et al. (1978) and Krieg \& Rogers (1995) detailed the lithology, stratigraphical relationships and outcrop distribution (including geological and locality maps) for the Allaru Mudstone together with its southern Eromanga Basin equivalent, the Oodnadatta Formation. Collectively, these successions comprise $c a 50-120 \mathrm{~m}$ of laminated claystone and siltstone, with fine-grained sandstone beds and abundant calcareous and ferruginous concretions (Krieg \& Rogers 1995). Age determinations for the Allaru Mudstone based on macroinvertebrates (Henderson et al. 2000, Henderson \& Kennedy 2002) and dinoflagellates/sporomorphs (Krieg \& Rogers 1995) place it within the late Albian Pseudoceratium ludbrookiae dinoflagellate zone/upper Phimopollenites pannosus
A
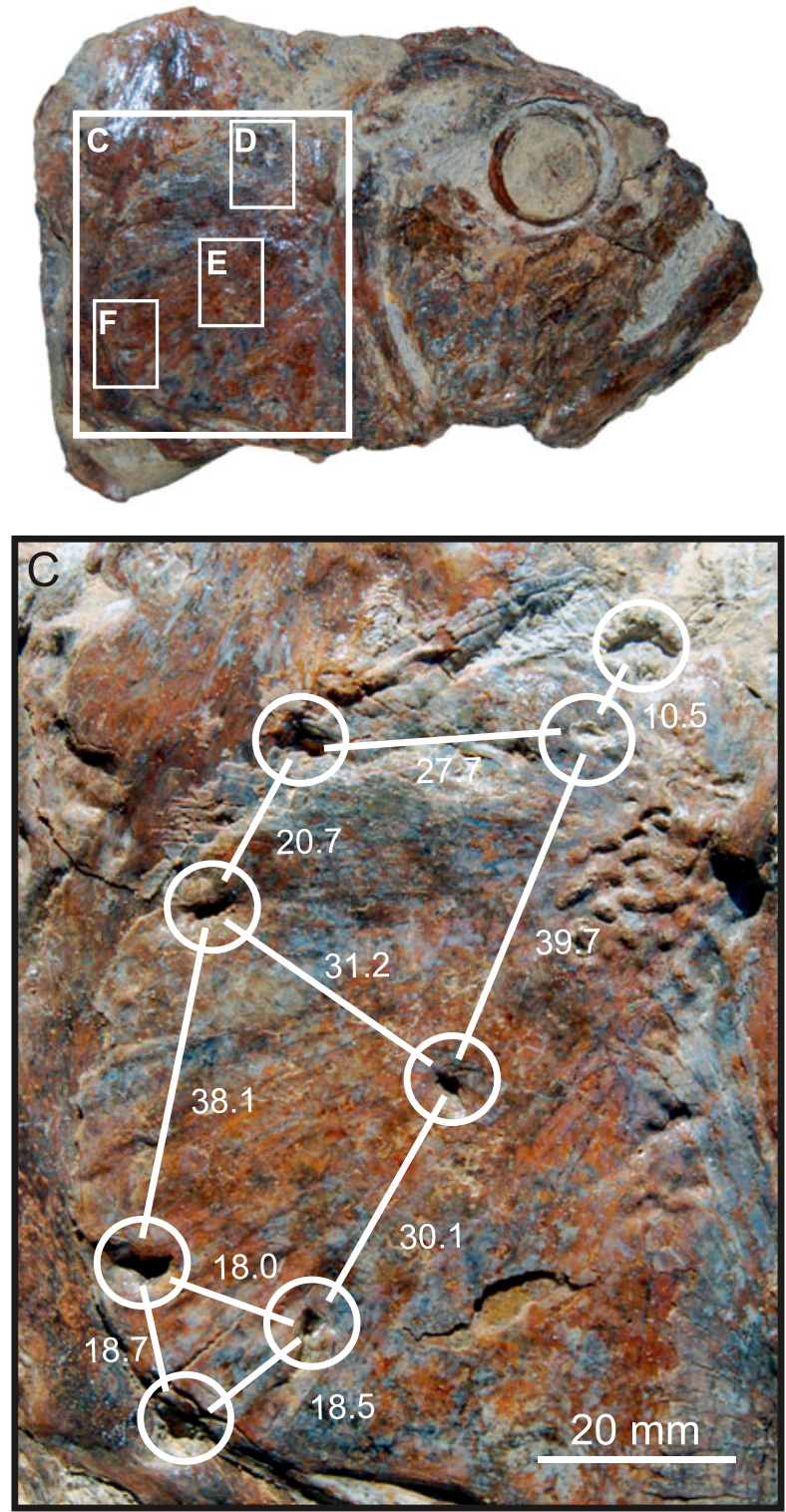

B
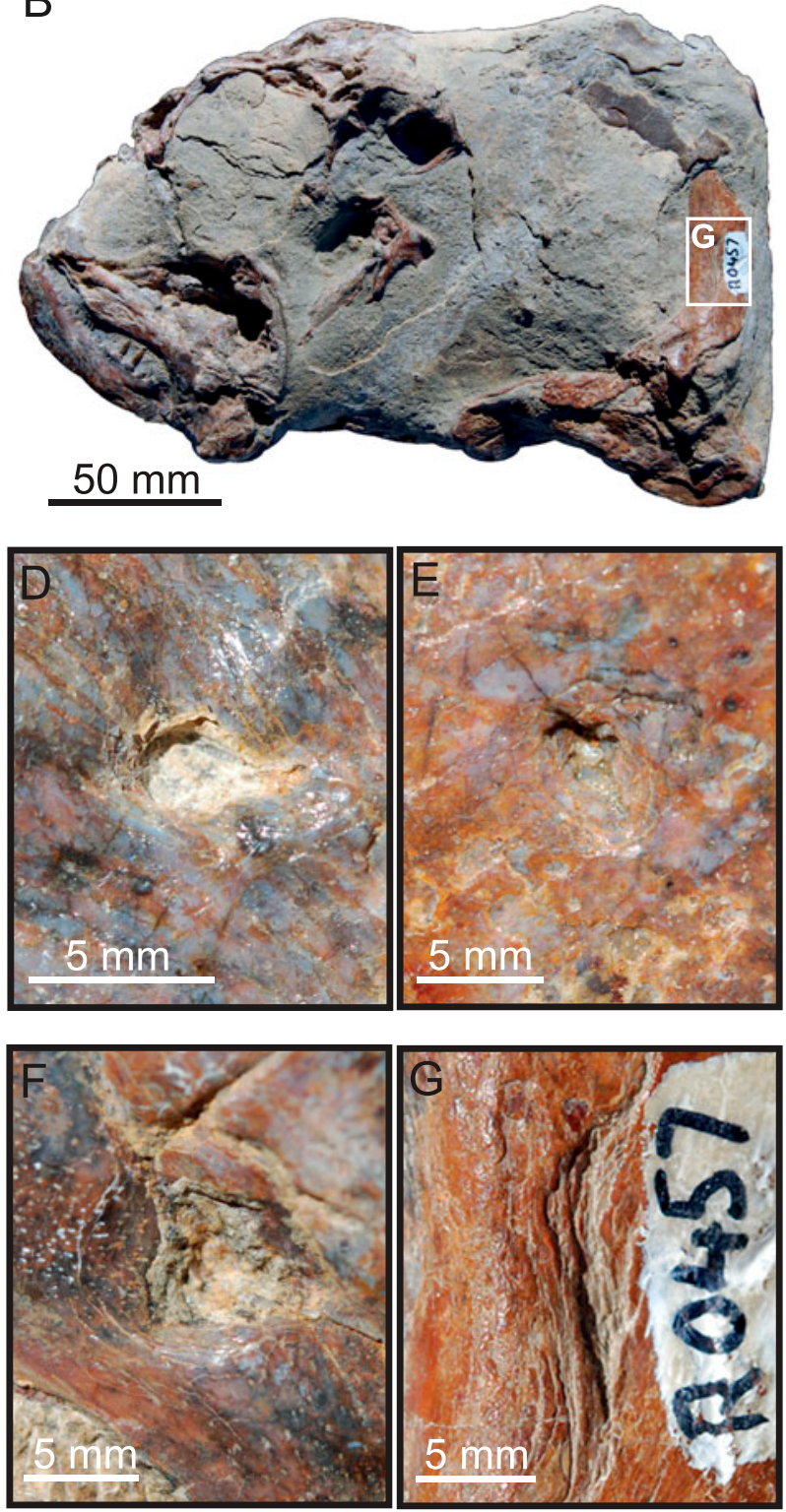

Fig 1. Cooyoo australis specimen KK R0457 displaying vertebrate bite marks. A, Right, and B, left-hand sides of the skull with areas of damage indicated by enlargements. C, Right opercular region with distribution of indentations and puncture marks indicated in millimetres. Exemplary enlargements of $\mathbf{D}$, a puncture, $\mathbf{E}$, indentation and $\mathbf{F}$, depression fracturing found on the right operculum and cleithrum. G, Enlargement of left cleithrum showing longitudinal gouge and crack. 
spore-pollen zone. This has been corroborated by Sr-isotope ratios, which likewise advocate a late Albian range (Williamson et al. 2012).

The Allaru Mudstone exposures at Richmond frequently yield fossils contained within limestone concretions that are disaggregated during exfoliation of the laminated parent rock. Invertebrate (ammonites, bivalves: Day 1969, Henderson et al. 2000, Henderson \& Kennedy 2002) and vertebrate remains (a possible dicynodont, dinosaurs, marine amniotes, fishes: Lees \& Bartholomai 1987, Molnar 1996, 2011, Kear 2003, Thulborn \& Turner 2003, Bartholomai 2004, 2008, 2010a, 2012, Molnar \& Salisbury 2005, Kear \& Hamilton-Bruce 2011) are typically articulated, suggesting accumulation in offshore environments with well-oxygenated surface waters but quiet bottom conditions. Palaeogeographical interpretations also reconstruct a regressive marine seaway that was contiguous with the southern Tethys Ocean via an open shelf connection through the Carpenteria Basin and Money Shoals Platform (Henderson 1998, Cook 2012).

\section{Identification and description}

KK R0457 can be confidently attributed to the ubiquitous Australian Early Cretaceous ichthyodectiform (Ichthyodectidae sensu Taverne \& Chanet, 2000) Cooyoo australis Lees \& Bartholomai, 1987 on the basis of its crested supraoccipital, anteriorly placed (within the orbital region) fused parietals, ridged frontals, maxillary dentition comprising small ( $c a 4 \mathrm{~mm})$ tooth crowns, deep maxillary-premaxillary attachment and corresponding mandibular symphysis and massive opercular (see Taverne 2008 for a character state synopsis). The skull as preserved (Fig. 1A, B) is 224.5/ $139.9 \mathrm{~mm}$ in maximum length/height, yielding an estimated total body length of $c a 1 \mathrm{~m}$ following the proportions reported by Lees \& Bartholomai (1987). The cranial roof of KK R0457 has collapsed and been displaced obliquely into a slanted orientation relative to the orbits. There are few remnants of the postcranium, although parts of both the left and right cleithra are exposed. The concave articular face of a vertebral centrum (embedded in matrix) is also visible posteriorly, and remains in life position towards the caudal end of the neurocranium. The left-hand side of the skull has been severely damaged by weathering, and the entire left orbital region and suspensorium are now lost. The left operculum has also been shunted dorsally and eroded away, probably during exposure on the surface; however, the adjacent left cleithrum is still in place and partly covered by matrix (Fig. 1B). In contrast, the right-hand side of the skull is fully articulated and almost completely intact, having suffered only superficial weathering (perhaps from plant roots) on the maxillary-premaxillary and infraorbital series of bones (Fig. 1A). The visible bite marks are localized to the right operculum (Fig. 1C), but possibly related bone modifications are also evident on the right and left cleithra (Fig. 1C, G). The right operculum bears eight irregular, crater-like indentations up to $3 \mathrm{~mm}$ deep and $5.5 \mathrm{~mm}$ in diameter (individual maximum diameter measurements taken clockwise from the dorsal-most are $2.8 \mathrm{~mm} ; 3.3 \mathrm{~mm} ; 2.9 \mathrm{~mm} ; 3.2 \mathrm{~mm} ; 2.9 \mathrm{~mm} ; 2.3 \mathrm{~mm}$; $2.6 \mathrm{~mm} ; 5.5 \mathrm{~mm}$ : see Fig. 1C). These are arranged in a narrow V-shaped pattern that extends $56.1 \mathrm{~mm}$ obliquely from the anterodorsal to posteroventral edge of the operculum and onto the exposed dorsal margin of the right cleithrum. The indentations are also regularly spaced (10.5-39.7 $\mathrm{mm}$ apart) and aligned along tapering longitudinal axes $31.2-18 \mathrm{~mm}$ wide. Towards the thinner peripheral margins of the operculum, the bony tissue has been completely punctured and there is a surrounding area of depression cone fracturing associated with all of the marks; this presumably resulted from collapse of the bone surface under point loading (see enlargements in Fig. 1D-F). Compatible modifications have been attributed to the ichnotaxon Nihilichnus nihilicus Mikuláš, Kadlecová, Fejfar \& Dvořák, 2006, which is characterized by triangular, circular or oval impact shapes surrounded by irregular fractures (Mikuláš et al. 2006).

It is unknown whether corresponding damage was evident on the left operculum, but two obvious marks $(5.6 / 2.5 \mathrm{~mm}$ in maximum diameter) are present on the left cleithrum. The dorsal-most of these is a shallow gouge (11.2 $\mathrm{mm}$ long) with a longitudinal crack running ventrally away from the centre of damage (Fig. 1G). This could either be biogeneic in origin, or the result of post-depositional compaction.

None of the identified bone modifications show traces of callus formation (deposition of osseous tissue at the site of trauma) or secondary zonal lamellar remodelling associated with healing. There are also no exostotic outgrowths or infectious abnormalities indicative of open wounds or adjacent soft tissue contagion (see Revell 1986, Aufderheide \& Rodriguez-Martin 1988).

\section{Interpretation and discussion}

Regularly spaced indentations/punctures with associated depression fractures and opposing placement on both the right and left opercular-pectoral regions of $\mathrm{KK}$ R0457 are compatible with vertebrate bite traces described in other fossil marine organisms (e.g., Shimada 1997, Tsujita \& Westermann 2001, Mikuláš et al. 2006, Boessenecker \& Perry 2011, Fahlke 2012). The absence of secondary osseous overgrowth or bone surface remodelling during healing also implies that the damage to KK R0457 occurred either peri- or postmortem. Despite this, the superficial nature of the modifications (puncture depth $\leqslant 3 \mathrm{~mm}$ ) suggests that they were not immediately fatal, nor were they proximal to any areas of vital fleshy tissue. Moreover, their tapered sub-parallel arrangement and oblique orientation 
across the anterodorsal to posteroventral sides of the skull indicate that the inflictor's jaws approached perpendicular to the longitudinal axis of the body with a slight $20^{\circ}$ craniad slant relative to its dorsal surface, rather than against the more vulnerable underside. The lack of tooth drag marks or closely adjacent punctures additionally accords with a single bite and there is no other obvious evidence of subsequent readjustment of the fish's head within the mouth (compare with the observations of Fahlke 2012).

The identity of the attacker is unknown. However, the characteristically diminutive dentition of Cooyoo australis, which comprises only a few slender dentary teeth (up to $10 \mathrm{~mm}$ high) followed by homodont rows of small conical crowns ( $c a 4 \mathrm{~mm}$ high) on the dentaries and premaxillae-maxillae (see Lees \& Bartholomai 1987 , p. 182, tables 1 , 2; p. 186, fig. 10), would seem to preclude an intraspecific encounter. Likewise, although ichthyodectiforms are known to have been macrophagous piscivores (e.g., Everhart et al. 2010), none of the other sufficiently large coeval actinopterygians (jaw length $\geqslant 55 \mathrm{~mm}$ ) have teeth that precisely match the tooth indentations on KK R0457, nor do they appear capable of puncturing and cracking fresh bone. For example, the edentulous aspidorhynchid Richmondichthys (Bartholomai 2004) and elopomorph Flindersichthys, which has a minute villiform dentition (Bartholomai 2010a), can obviously be discounted. The common pachyrhizodont Pachyrhizodus (Bartholomai 2012) and rare possible albuloid Euroka (Bartholomai 2010b) are both similar to Cooyoo in possessing small marginal crowns (up to around $5 \mathrm{~mm}$ high) and only a few larger teeth ( $c a 10 \mathrm{~mm}$ long) at the anterior-most tip of the dentary or palatal midline, respectively. Lastly, the pachycormid Australopachycormus exhibits a distinctive arrangement of procumbent and upright lanceolate fangs $(20 \mathrm{~mm}$ high $)$ that are thin and separated by wide diastemae, together with an isolated medial pair of rearward-pointing rostral blades and convex rows of closely spaced, triangular teeth on the laterally situated premaxillae (Kear 2007). In light of these inconsistencies, we propose that the bite marks on KK R0457 were more likely made by a non-actinopterygian predator.

KK R0457 is not among the largest-known specimens of Cooyoo australis (Lees \& Bartholomai 1987 and Kear \& Hamilton-Bruce 2011 have reported skulls up to $400 \mathrm{~mm}$ long), but was substantial enough ( $c a$ $1 \mathrm{~m}$ long in life: Lees \& Bartholomai 1987) to have made an attractive prey item for various sympatric sharks and amniotes. Certainly, many macrocarnivorous selachian species, together with marine reptiles and pterosaurs, are present in the Allaru Mudstone and slightly older Toolebuc Formation assemblages (see Kear \& Hamilton-Bruce 2011 for faunal summaries). Sharks, however, can be excluded because their feeding traces characteristically comprise parallel sets of cuts or steep-sided punctures usually arranged in a wide arc (e.g., Shimada 1997). Similarly, the colossal pliosaurid Kronosaurus, which is known to have fed upon large vertebrates (e.g., elasmosaurids and lamniforms: Thulborn \& Turner 1993, 2003), has massive, widely spaced teeth (up to $250 \mathrm{~mm}$ long from the base of the root, with a crown height of $100 \mathrm{~mm}$ and apical separation of around $80 \mathrm{~mm}$ : Longman 1924, White 1935, Thulborn \& Turner 1993) that would have inflicted severe crushing and breakage (see example illustrated by Thulborn \& Turner 1993). The short, triangular snout of the elasmosaurid Eromangasaurus (Kear 2005a) is likewise too broad $(73 \mathrm{~mm}$ wide based on the holotype skull QM F11050) and, incongruously, bears procumbent fangs with widely divergent distal apexes (around $34 \mathrm{~mm}$ apart measured from QM F11050). Polycotylid plesiosaurians (see Kear \& Hamilton-Bruce 2011, p. 102), the ornithocheiroid pterosaur Mythunga (Molnar \& Thulborn 2007, Fletcher \& Salisbury 2010) and the endemic ichthyosaurian Platypterygius australis (Kear 2005b), on the other hand, all possessed suitably narrow maxillary and mandibular rostra together with stout conical teeth that could have indented and punctured bone. The Allaru Mudstone polycotylid taxon has yet to be described but exhibits anteriorly inclined, massive teeth (up to $25 \mathrm{~mm}$ in diameter in QM F18041: BPK pers. obs.) at the front of both the premaxillae and dentaries. Dentigerous fragments from Mythunga (Molnar \& Thulborn 2007) and other ornithocheiroids (Aussiedraco and indeterminate remains: Fletcher \& Salisbury 2010, Kellner et al. 2011) are also commonly delicate (QM F44423, the distal part of the mandible described by Fletcher \& Salisbury 2010 , measures only $18.5 \mathrm{~mm}$ at its broadest point). Given our interpretation, the ichthyosaurian P. australis, therefore, displays the most compatible tooth arrangement with compact tooth rows $c a$ $40 \mathrm{~mm}$ apart and vertically oriented crowns separated by gaps of $c a 20 \mathrm{~mm}$ (based on the articulated individual QM F2453). Kear (2005b) suggested that $P$. australis probably fed on small-bodied cephalopods and vertebrates; however, vigorous dismemberment of large, bony prey items appears feasible based on tooth wear patterns and dental pathology (see Kear 2001). Indeed, this conclusion is strengthened by the discovery of isolated Cooyoo-like remains within the gut contents of at least one P. australis individual (Kear et al. 2003).

\section{Conclusions and implications}

The recognition of preserved vertebrate bite traces on the Cooyoo australis specimen KK R0457 not only provides the first documented example of a bite-modified actinopterygian fossil from Australia (previous examples include digested remnants in coprolites: Beattie \& Avery 2012), but also elucidates potential interspecific interactions within the Early Cretaceous marine lagerstätten assemblages of the Eromanga Basin. Interestingly, the distribution and spacing of the individual tooth impact depressions/punctures does 
not match the dentition of conspecific individuals, nor does it comply with any other described actinopterygian or selachian that occurs sympatrically. Rather, the conspicuously narrow bite mark arrangement and associated fracturing indicates an encounter with a longirostrine amniote that bore small, robust teeth, perhaps a polycotylid plesiosaurian (see Kear \& Hamilton-Bruce 2011, p. 102 for comparative image), ornithocheiroid pterosaur (e.g., Mythunga: Molnar \& Thulborn 2007, Fletcher \& Salisbury 2010) or the coeval ichthyosaurian Platypterygius australis (e.g., Kear 2005b). Whether this event was accidental (non-feeding), predatory or scavenging is unknown but, tellingly, only $P$. australis has been directly identified as having fed upon large fish such as Cooyoo (Kear et al. 2003). In addition, the unusual orientation of the bite, which was directed against the dorsal side of the skull, could imply that the body was floating and either inverted or prone at the surface; this accords with the absence of healing and indicates that the animal was already dead or dying when attacked. The non-lethal condition of the damage also suggests that fatal injuries (if any) must have been located on the postcranium. Note however that there are no obvious traces of violent disarticulation on the cleithra or exposed vertebral centrum. Irrespectively, this scenario infers that KK R0457 was a potential prey item and could have been either actively hunted or opportunistically scavenged. Subsequent trophic implications infer a hierarchical relationship, in which intermediate-level predators such as Cooyoo appear to have constituted prey for high-level consumers, feasibly represented in this case by an ichthyosaurian (see also Kear et al. 2003). This is consistent with other Early Cretaceous epeiric communities (e.g., the Santana Formation of Brazil: see Maisey 1994), in which actinopterygians constitute a prominent component of the lower- to middle-level trophic niches. Uniquely, however, the Toolebuc Formation and Allaru Mudstone lagerstätten have also yielded direct evidence of marine amniotes as intermediate-level benthic 'grazers' (protostegid turtles, elasmosaurs: McHenry et al. 2005, Kear 2006) and apex carnivores (Kronosaurus: Thulborn \& Turner 1993, Turner \& Thulborn 2003), thus occupying ecological niches not unlike their marine mammal equivalents of today.

\section{Acknowledgments}

Thanks to Paul Stumkat (Stumkat Studios, Natural History Art) for assistance with regional museum collections access, field logistics and information. Henning Blom (Uppsala University) commented on earlier drafts of this manuscript. Robert Boessenecker (University of Otago), Michael Everhart (Sternberg Museum of Natural History, Fort Hays State University) and Stephen McLoughlin (Swedish Natural History Museum) also contributed constructive reviews and editorial input. LW acknowledges financial support from the Anna Maria Lundins Stipendiefond; BPK was funded by the Australian Research Council, Swedish Research Council and Sir Mark Mitchell Research Fund.

\section{References}

Aufderheide, C.A. \& Rodriguez-Martin, C., 1988. The Cambridge Encyclopedia of Human Palaeopathology. Cambridge University Press, New York, 496 pp.

Barnes, K.M. \& Hiller, N., 2010. The taphonomic attributes of a Late Cretaceous plesiosaur skeleton from New Zealand. Alcheringa 34, 333-344.

Bartholomai, A., 2004. The large aspidorhymchid fish Richmondichthys sweeti (Etheridge Jr and Smith Woodward 1891) from Albian marine deposits of Queensland Australia. Memoirs of the Queensland Museum 49, 521-536.

BARTHOLOMAI, A., 2008. Lower Cretaceous Chimaeroids (Chondrichthyes: Holocephali) from the Great Artesian Basin, Australia. Memoirs of the Queensland Museum 52, 49-56.

Bartholomai, A., 2010a. Revision of Flindersichthys denmeadi Longman 1932, a marine teleost from the Lower Cretaceous of the Great Artesian Basin, Queensland. Memoirs of the Queensland Museum 55, 43-68.

Bartholomai, A., 2010b. A new Albian teleost, Euroka dunravenensis gen. et sp. nov., and a new family, Eurokidae, from the Eromanga Basin of Queensland. Memoirs of the Queensland Museum 55, 69-85.

Bartholomai, A., 2012. The pachyrhizodontid teleosts from the marine Lower Cretaceous (latest mid to late-Albian) sediments of the Eromanga Basin, Queensland, Australia. Memoirs of the Queensland Museum 56, 119-148.

Beattie, R.G. \& Avery, S., 2012. Palaeoecology and palaeoenvironment of the Jurassic Talbragar Fossil Fish Bed, Gulgong, New South Wales, Australia. Alcheringa 36, 453-468.

Boessenecker, R.W. \& Perry, F.A., 2011. Mammalian bite marks on juvenile fur seal bones from the late Neogene Purisima Formation of central California. Palaios 26, 115-120.

Cicimurri, D.J. \& Everhart, M.J., 2001. An elasmosaur with stomach contents and gastroliths from the Pierre Shale (Late Cretaceous) of Kansas. Transactions of the Kansas Academy of Science 104, $129-143$.

Cook, A.G., 2012. Cretaceous faunas and events, northern Eromanga Basin, Queensland. Episodes 35, 153-159.

DAy, R.W., 1969. The Lower Cretaceous of the Great Artesian Basin. In Stratigraphy and Palaeontology: Essays in Honour of Dorothy Hill. CampBell, K.S.W., ed., Australian National University Press, Canberra, 140-173.

Einarsson, E., Lindgren, J., Kear, B.P. \& Siverson, M., 2010. Mosasaur bite marks on a plesiosaur propodial from the Campanian (Late Cretaceous) of southern Sweden. GFF 132, 123-128.

Eriksson, M.E., Lindgren, J., Chin, K. \& MAnsby, U., 2011. Coprolite morphotypes from the Upper Cretaceous of Sweden: novel views on an ancient ecosystem and implications for coprolite taphonomy. Lethaia 44, 455-468.

Everhart, M.J., 2004a. Plesiosaurs as the food of mosasaurs; new data on the stomach contents of a Tylosaurus proriger (Squamata; Mosasauridae) from the Niobrara Formation of western Kansas. The Mosasaur 7, 41-46.

Everhart, M.J., 2004b. Late Cretaceous interaction between predators and prey. Evidence of feeding by two species of shark on a mosasaur. PalArch, Vertebrate Palaeontology 1, 1-7.

Everhart, M.J., 2005. Bite marks on an elasmosaur (Sauropterygia; Plesiosauria) paddle from the Niobrara Chalk (Upper Cretaceous) as probable evidence of feeding by the lamniform shark, Cretoxyrhina mantelli. PalArch, Vertebrate Palaeontology 2, 14-24.

Everhart, M.J., 2007. Remains of a pycnodont fish (Actinopterygii: Pycnodontiformes) in a coprolite; an upper record of Micropycnodon kansasensis in the Smoky Hill Chalk, western Kansas. Transactions of the Kansas Academy of Science 110, 35-43.

Everhart, M.J., 2008. A bitten skull of Tylosaurus kansasensis (Squamata: Mosasauridae) and a review of mosasaur-on-mosasaur pathology in the fossil record. Transactions of the Kansas Academy of Science 111, 251-262. 
EverharT, M.J. \& HAMm, S.A., 2005. A new nodosaur specimen (Dinosauria: Nodosauridae) from the Smoky Hill Chalk (Upper Cretaceous) of western Kansas. Transactions of the Kansas Academy of Science 108, 15-21.

Everhart, M.J., Hageman, S.A. \& Hoffman, B.L., 2010. Another Sternberg "Fish-within-a-Fish" discovery: first report of Ichthyodectes ctenodon (Teleostei; Ichthyodectiformes) with stomach contents. Transactions of the Kansas Academy of Science 113, 197-205.

FAHLKE, J.M., 2012. Bite marks revisited - evidence for middle-tolate Eocene Basilosaurus isis predation on Dorudon atrox (both Cetacea, Basilosauridae). Palaeontologia Electronica 15 (32A), $1-16$.

Fletcher, T.L. \& Salisbury, S.W., 2010. New pterosaur fossils from the Early Cretaceous (Albian) of Queensland, Australia. Journal of Vertebrate Paleontology 30, 1747-1759.

ForRest, R., 2003. Evidence for scavenging by the marine crocodile Metriorhynchus on the carcass of a plesiosaur. Proceedings of the Geologists' Association 114, 363-366.

Frey, E., Buchy, M., Stinnesbeck, W. \& Lopez-Oliva, J.G., 2002. Geosaurus vignaudi n. sp. (Crocodyliformes: Thalattosuchia), first evidence of metriorhynchid crocodilians in the Late Jurassic (Tithonian) of central-east Mexico (State of Puebla). Canadian Journal of Earth Sciences 39, 1467-1483.

Harrell, S.D. \& Schwimmer, D.R., 2010. Coprolites of Deinosuchus and other crocodylians from the Upper Cretaceous of western Georgia, USA. New Mexico Museum of Natural History and Science Bulletin 51, 209-214.

HatTin, D.E., 1996. Fossil regurgitate from Smoky Hill Member of Niobrara Chalk (Upper Cretaceous) of Kansas. Cretaceous Research 17, 443-450.

HendERson, R.A., 1998. Eustatic and palaeoenvironmental assessment of the mid-Cretaceous Bathurst Island Group of the Money Shoals Platform, northern Australia. Palaeogeography, Palaeoclimatology, Palaeoecology 138, 115-138.

Henderson, R.A. \& KenNedy, W.J., 2002. Occurrence of the ammonite Goodhallites goodhalli (J. Sowerby) in the Eromanga Basin, Queensland: an index species for the late Albian (Cretaceous). Alcheringa 26, 233-247.

Henderson, R.A., Crampton, J.S., Dettmann, M.E., Douglas, J.G., Haig, D., ShafiK, S., Stilwell, J.D. \& Thulborn, R.A., 2000 Biogeographical observations on the Cretaceous biota of Australasia. Memoirs of the Association of Australasian Palaeontologists $23,355-404$.

Kaddumi, H.F., 2006. A new genus and species of gigantic marine turtles (Chelonoidea: Cheloniidae) from the Maastrichtian of the Harrana Fauna-Jordan. PalArch, Vertebrate Palaeontology 3, $1-14$.

Kauffman, E.G., 1972. Ptychodus predation upon a Cretaceous Inoceramus. Palaeontology 15, 439-444.

Kauffman, E.G., 2004. Mosasaur predation on Upper Cretaceous nautiloids and ammonites from the United States Pacific coast Palaios 19, 96-100.

Kauffman, E.G. \& Kesling, R.V., 1960. An Upper Cretaceous ammonite bitten by a mosasaur. Contributions from the Museum of Paleontology, University of Michigan 15, 193-248.

Kauffman, E.G. \& SAwDo, J.K., 2013. Mosasaur predation on a nautiloid from the Maastrichtian Pierre Shale, Central Colorado, Western Interior Basin, United States. Lethaia 46, 180-187.

KeAR, B.P., 2001. Dental caries in an Early Cretaceous ichthyosaur Alcheringa 25, 387-390

KeAR, B.P., 2003. Cretaceous marine reptiles of Australia: a review of taxonomy and distribution. Cretaceous Research 24, 277-303.

KeAR, B.P., 2005a. A new elasmosaurid plesiosaur from the Lower Cretaceous of Queensland, Australia. Journal of Vertebrate Paleontology 25, 792-805.

KeAR, B.P., 2005b. Cranial morphology of Platypterygius longmani Wade, 1990 (Reptilia: Ichthyosauria) from the Lower Cretaceous of Australia. Zoological Journal of the Linnean Society $145,583-622$.

KeAR, B.P., 2006. First gut contents in a Cretaceous sea turtle. Biology Letters 2, 113-115.
KeAR, B.P., 2007. First record of a pachycormid fish (Actinopterygii: Pachycormiformes) from the Lower Cretaceous of Australia. Journal of Vertebrate Paleontology 27, 1033-1038.

KeAR, B.P. \& Godthelp, H., 2008. Inferred vertebrate bite marks on an Early Cretaceous unionoid bivalve from Lightning Ridge, New South Wales, Australia. Alcheringa 32, 65-71.

Kear, B.P. \& Hamilton-Bruce, R.J., 2011. Dinosaurs in Australia. Mesozoic Life from the Southern Continent. CSIRO Publishing, Melbourne, $190 \mathrm{pp}$.

Kear, B.P., Boles, W.E. \& Smith, E.T., 2003. Unusual gut contents in a Cretaceous ichthyosaur. Proceedings of the Royal Society of London, Series B 270, S206-S208.

Kellner, A.W.A., Rich, T.H., Costa, F.R., Vickers-Rich, P., Kear, B. P., Walters, M. \& Kool, L., 2010. New isolated pterodactyloid bones from the Albian Toolebuc Formation (western Queensland, Australia) with comments on the Australian pterosaur fauna. Alcheringa 34, 219-230.

Kellner, A.W.A., Rodrigues, T. \& Costa, F.R., 2011. Short note on a pteranodontoid pterosaur (Pterodactyloidea) from western Queensland, Australia. Anais da Academia Brasileira de Ciências 83, 301-308.

Klompmaker, A.A., WaljaArd, N.A. \& FraAiJe, R.H.B., 2009. Ventral bite marks in Mesozoic ammonoids. Palaeogeography, Palaeoclimatology, Palaeoecology 280, 245-257.

KRIEG, G.W. \& Rogers, P.W., 1995. Stratigraphy - marine succession. In The Geology of South Australia. Volume 2, The Phanerozoic. Drexell, J.F. \& Preiss, W.V., eds, South Australia Geological Survey Bulletin, Adelaide, 112-123.

Lees, T. \& Bartholomai, A., 1987. Study of a Lower Cretaceous actinopterygian (Class Pisces) Cooyoo australis from Queensland, Australia. Memoirs of the Queensland Museum 25, 177-192.

Lingham-Soliar, T., 1995. Anatomy and functional morphology of the largest marine reptile known, Mosasaurus hoffmanni (Mosasauridae, Reptilia) from the Upper Cretaceous, upper Maastrichtian of The Netherlands. Philosophical Transactions of the Royal Society of London B 347, 155-172.

Lingham-Soliar, T., 2004. Paleopathology and injury in the extinct mosasaurs (Lepidosauromorpha, Squamata) and implications for modern reptiles. Lethaia 37, 255-262.

Longman, H.A., 1924. Some Queensland fossil vertebrates. Memoirs of the Queensland Museum 10, 16-28.

MAISEY, J.G., 1978. Growth and form of finspines in hybodont sharks. Palaeontology 21, 657-666.

Maisey, J.G., 1994. Predator-prey relationships and trophic level reconstruction in a fossil fish community. Environmental Biology of Fishes 40, 1-22.

Martill, D.M., 1990. Predation on Kosmoceras by semionotid fish in the Middle Jurassic lower Oxford Clay of England. Palaeontology 33, 739-742.

MartiLl, D.M., 1996. Fossils explained: ichthyosaurs. Geology Today 12, 194-196.

Martin, J.E. \& Fox, J.E., 2007. Stomach contents of Globidens, a shell-crushing mosasaur (Squamata), from the Late Cretaceous Pierre Shale Group, Big Bend area of the Missouri River, central South Dakota. Special Papers, Geological Society of America 427, 167-176.

Martin, J.E. \& Kennedy, L.E., 1988. A plesiosaur from the Late Cretaceous (Campanian) Pierre Shale of South Dakota: a preliminary report. Proceedings of the South Dakota Academy of Science 67, 76-79.

McHenry, C.R., Cook, A.G. \& Wroe, S., 2005. Bottom-feeding plesiosaurs. Science 310, 75.

Mikuláš, R., Kadlecová, E., Fejfar, O. \& Dvořák, Z., 2006. Three new ichnogenera of biting and gnawing traces of reptilian and mammalian bones: a case study from the Miocene of Czech Republic. Ichnos 13, 113-127.

MolnaR, R.E., 1996. Preliminary report on a new ankylosaur from the Early Cretaceous of Queensland, Australia. Memoirs of the Queensland Museum 39, 653-668.

Molnar, R.E., 2011. New morphological information about Cretaceous sauropod dinosaurs from the Eromanga Basin, Queensland, Australia. Alcheringa 35, 329-339. 
Molnar, R.E. \& SalisburY, S.W., 2005. Observations on Cretaceous sauropods from Australia. In Thunder-Lizards: The Sauropodomorph Dinosaurs. CARPenter, K. \& Tidwell, V., eds, Indiana University Press, Bloomington, 454-465.

Molnar, R.E. \& Thulborn, R.A., 2007. An incomplete pterosaur skull from the Cretaceous of north-central Queensland, Australia. Arquivosdo Museu Nacional 65, 461-470.

Neumann, C., 2000. Evidence of predation on Cretaceous sea stars from north-west Germany. Lethaia 33, 65-70.

Олі, Т., OgaYa, C. \& Sato, T., 2003. Increase of shell crushing predation recorded in fossil shell fragmentation. Paleobiology 29, 520-526.

O’Keefe, F.R., Street, H.P., Cavigelli, J.P., Socha, J.J. \& O'Keefe, R.D., 2009. A plesiosaur containing an ichthyosaur embryo as stomach contents from the Sundance Formation of the Bighorn Basin, Wyoming. Journal of Vertebrate Paleontology 29, 1306-1310

Pollard, J.E., 1968. The gastric contents of an ichthyosaur from the lower Lias of Lyme Regis, Dorset. Palaeontology 11, 376-388.

Revell, P.A., 1986. Pathology of Bone. Springer-Verlag, Berlin, 451 pp.

Rothschild, B.M., Martin, L.D. \& Schulp, A.S., 2005. Sharks eating mosasaurs, dead or alive? Netherlands Journal of Geosciences 84, $335-340$.

Salamon, M.A., Niedźwiedzki, R., Gorzelak, P., Lach, R. \& Surmik, D., 2012. Bromalites from the Middle Triassic of Poland and the rise of the Mesozoic Marine Revolution. Palaeogeography, Palaeoclimatology, Palaeoecology 321-322, 142-150.

Sato, T. \& Tanabe, K., 1998. Cretaceous plesiosaurs ate ammonites. Nature 394, 629-630.

Schwimmer, D.R., Stewart, J.D. \& Williams, G.D., 1997. Scavenging by sharks of the genus Squalicorax in the Late Cretaceous of North America. Palaios 12, 71-83.

Senior, B.R., Mond, A. \& Harrison, P.L., 1978. Geology of the Eromanga Basin. Australia. Bureau of Mineral Resources, Geology and Geophysics 167, 1-102.

Shimada, K., 1997. Paleoecological relationships of the Late Cretaceous lamniform shark, Cretoxyrhina mantelli (Agassiz). Journal of Paleontology 71, 926-933.

Shimada, K. \& Everhart, M.J., 2004. Shark-bitten Xiphactinus audax (Teleostei: Ichthyodectiformes) from the Niobrara Chalk (Upper Cretaceous) of Kansas. The Mosasaur 7, 35-39.

Shimada, K. \& Fielitz, C., 2006. Annotated checklist of fossil fishes from the Smoky Hill Chalk of the Niobrara Chalk (Upper Cretaceous) in Kansas. New Mexico Museum of Natural History and Science Bulletin 35, 193-213.

SHIMADA, K. \& HooKs, G.E.III, 2004. Shark-bitten protostegid turtles form the Upper Cretaceous Mooreville Chalk, Alabama. Journal of Paleontology 78, 205-210.
Shimada, K., TsuiniJi, T., Sato, T. \& Hasegawa, Y., 2010. A remarkable case of a shark-bitten elasmosaurid plesiosaur. Journal of Vertebrate Paleontology 30, 592-597.

TAVERne, L., 2008. Considerations about the Late Cretaceous genus Chirocentrites and erection of the new genus Heckelichthys (Teleostei, Ichthyodectiformes) - A new visit inside the ichthyodectid phylogeny. Bulletin de l'Institut royal des Sciences naturelles de Belgique, Sciences de la Terre 78, 209-228.

Taverne, L. \& Chanet, B., 2000. Faugichthys loryi n. gen., n. sp. (Teleostei, Ichthyodectiformes) de l'Albien terminal (Crétacé inférieur marin) du vallon de la Fauge (Isère, France) et considérations sur la phylogénie des Ichthyodectidae. Geodiversitas 22, 23-34.

Thulborn, T. \& Turner, S., 1993. An elasmosaur bitten by a pliosaur. Modern Geology 18, 489-501.

Thulborn, T. \& Turner, S., 2003. The last dicynodont: an Australian Cretaceous relict. Proceedings of the Royal Society of London, Series B 270, 985-993.

Tsujta, C.J. \& Westermann, G.E.G., 2001. Were limpets or mosasaurs responsible for the perforations in the ammonite Placenticeras? Paleogeography, Paleoclimatology, Paleoecology $169,245-270$.

Turner, S. \& Thulborn, T., 2003. Second course for Kronosaurus? Further evidence of pliosaur predation in the Cretaceous of Queensland. In Abstracts, 9th Conference on Australasian Vertebrate Evolution, Palaeontology \& Systematics - Heber A. Longman Symposium, Brisbane, 29-30.

VulLo, R., 2011. Direct evidence of hybodont shark predation on Late Jurassic ammonites. Naturwissenschaften 98, 545-549.

WARD, D.J. \& HollingworTh, N.T.J., 1990. The first record of a bitten ammonite from the Middle Oxford Clay (Callovian, Middle Jurassic) of Bletchley, Buckinghamshire. Mesozoic Research 2, $153-161$.

White, T.E., 1935. On the skull of Kronosaurus queenslandicus Longman. Occasional Papers of the Boston Society of Natural History 8, 219-228.

WilbY, P.R. \& MARTILL, D.M., 1992. Fossil fish stomachs: a microenvironment for exceptional preservation. Historical Biology 6, 25-36.

Williamson, T., Henderson, R.A., Price, G.D. \& Collerson, K.D., 2012. Strontium-isotope stratigraphy of the Lower Cretaceous of Australia. Cretaceous Research 36, 24-36.

Zammit, M. \& KeAR, B.P., 2011. Healed bite marks on a Cretaceous ichthyosaur. Acta Palaeontologica Polonica 56, 859-863.

Zatoń, M. \& Salamon, M.A., 2008. Durophagous predation on Middle Jurassic molluscs, as evidenced from shell fragmentation. Palaeontology 51, 63-70. 